\title{
Voter Turnout and the Electoral Crisis
}

Catus Brooks* and Jocelyne Praud

Department of Humanities, University of Victoria, British Columbia, Canada

*Corresponding author: Catus Brooks, Professor, Department of Humanities, University of Victoria, British Columbia, Canada, Tel: 1-250-721-7211; E-mail: sirgraciousness@gmail.com

Received date: March 01, 2018; Accepted date: March 08, 2018; Published date: March 15, 2018

Copyright: $\odot 2018$ Brooks C, et al. This is an open-access article distributed under the terms of the Creative Commons Attribution License, which permits unrestricted use, distribution, and reproduction in any medium, provided the original author and source are credited.

\begin{abstract}
The purpose of this article is to provide a current understanding of the Canadian electoral politics crisis of 2016. This study in Canadian party politics is justified by the 2008 Canadian federal election results, which was the lowest in Canadian history, only $58.8 \%$ of eligible Canadians voted. It is a primitive of an electoral democracy to have a healthy voter turnout, since voters tend to be the ones shaping policy. If the crisis at stake is ignored, then this is an indication that Canada's electoral system is at risk, as the lesser the voter turnout, the lesser the political equality of a country. This research demonstrates that Canadian political parties and the provincial and federal government of Canada should institute publicly funded post-secondary education, proportional representation (PR), and other mechanisms to increase voter turnout. The methods used in this examination include categorical analyses, a comparative case study, media analyses, statistical analyses, and dialectic. The results of this essay underline the role of Canadian political parties in the electoral crisis, and suggest that there is opportunity for Canadian political parties to win positions of power by increasing equality, and thereby the voter turnout, in Canada.
\end{abstract}

Keywords: Canadian political parties; Electoral democracy; Politics; Publicly funded post-secondary education; Voting age; Voter turnout; Proportional representation (PR)

\section{Review of Electoral Democracy}

Canada's electoral democracy is undergoing an electoral crisis. Since the 1980s, voter turnout in Canada has been rapidly declining. Voter turnout for the 2015 federal election was only 68.3\% [1]. Although $68.3 \%$ is a slight increase in voter turnout since 2008 , it is still alarming for Canada's electoral democracy. Further, in the 2008 federal election, Canadian voter turnout was the lowest in Canadian history, a mere $58.8 \%$ [2]. If effective action is not undertaken to counter this decline in electoral participation, then Canada's electoral democracy will be at risk. Therefore, the overall argument of this essay is that the Canadian government and Canadian federal parties should take the necessary steps to improve voter turnout. In this essay, when we use the term parties, we refer to Canadian federal parties.

To understand the general decline in Canadian voter turnout, we will establish the reasons for the decline. We demonstrate that the Liberal Party of Canada (LPC) has attempted, in some cases, to increase voter turnout; however, parties, especially the Conservative Party of Canada (CPC), are still a significant cause in the decrease in voter turnout. Furthermore, we analyze the necessary steps that parties and the Canadian government should take to increase voter turnout. We analyze the use of technology by parties, and the electoral prospect of technology and political literacy. We argue that to increase voter turnout, PR and publicly funding post-secondary education should be instituted. We show that PR, publicly funded post-secondary education, and the Canadian regime are all compatible. To show that PR and publicly funded post-secondary education will increase voter turnout, we briefly analyze a case study of Norway and Sweden. Also, we argue that the legal minimum voting age in Canada should be lowered to sixteen. Lastly, we underline the prospects for parties to utilize new infrastructural developments, and show that the Green Party of Canada (GPC) has supported electoral reform.

Voter turnouts are important determinants in understanding the health of a democracy. A determinant is a determining factor. The health of a democracy means the vitality of a democracy. LaRochelleCote and Uppal [3] write that voting is one of the most fundamental aspects of civic engagement. Many political scientists link voting with the health of the democratic process and argue that declining voting rates may be symptomatic of a "democratic deficit". Because political participation can also influence public policy, others are concerned that lower participation could result in policies that are not necessarily representative of key constituencies, like those who tend to vote less. As a result, the voter turnout rate is used as one indicator of civic engagement.

This quote highlights the electoral crisis. With a decreasing voter turnout, Canada's democratic regime is at risk. By consequence, the electoral crisis could result with Canadian people being underrepresented. The people that vote are the primary people influencing political policies; therefore, there is a risk in non-voters being underrepresented, and political policies not reflecting their needs.

Furthermore, the reasons for the recent decline in the Canadian voter turnout are complex. One reason lies at the foundation of political parties. With the exception of the New Democratic Party (NDP), there is a lack of mass parties in Canada. Steven Wolinetz writes that "mass parties attempt to enlist all of their supporters as members and involve them in a wide range of activities between elections" [4]. Rather, the major parties in Canada, the LPC and CPC, share cadre party elements. This means, in particular, that the LPC and the CPC "have minimal organization outside the government" [4]. This has a negative impact on voter turnout. Parties, not having sufficient involvement outside of government and in between elections, generally neglect encouraging people to vote. 
Though parties are supposed to be responsible to ensure people vote, their actions with regard to voter turnout are instead pragmatic. Pragmatic in this context means practical and calculative, as opposed to being programmatic. Programmatic here means to have an overarching plan or policy, like encouraging everyone to vote, regardless of what party they vote for. Being programmatic differs from being pragmatic, because parties that are programmatic tend to be unwavering in their policies and ideological positions. Whereas, parties that are pragmatic will tend to prioritize immediate interests above ideology. Pragmatism is an element of the cadre party. The LPC and the CPC tend to be pragmatic, not inconveniencing themselves trying to encourage people to vote. They encourage people to vote for their particular party, but, at times, discourage all other people from voting.

To a worse extent, some parties even engage in illegal forms of electioneering. Electioneering here means simply to support or be a part of a political organization during an election. This can be exemplified with the CPC in 2011 using "misleading robocalls" (Keys Facts and Timeline of Events Surrounding the Robocalls Scandal, to direct "voters to the wrong polling stations" (Keys Facts and Timeline of Events Surrounding the Robocalls Scandal [5]. In the Summary Investigation Report on Robocalls, the Commissioner of Canada Elections states that under section 110 of the Act, parties are entitled to use voters' list information for the purpose of communicating with electors and for soliciting contributions [5]. They are, however, prohibited from knowingly using the personal information of electors for a purpose other than one in accordance with section 110.

In 2011, many voters were deceived by the CPC into travelling to the wrong location to cast their vote during elections. Consequently, when a voter is limited for time, the voter could choose to miss the election. Already, with the frustration and discontent during elections, people can be discouraged from voting if they are inconvenienced by political parties. Bernadette LaMontagne, Daniel Stockemer, and Lyle Scruggs write that "through instrumental variable regression we find that as corruption increases the percentage of voters who go to the polls decreases" [6]. Clearly, these illegal practices of parties are a cause in the enormous decline in voter turnouts.

In addition, parties do not only illegally electioneer, discouraging people from voting when voters are not voting for their party, they also idle in between elections. Wolinetz states that "parties go into high gear in the run-up to election campaigns and in some instances leadership contests, and slacken off in between" [4]. This means that during election campaigns and leadership contests, parties are highly active in encouraging people to vote. However, when the elections and leadership contests are finished, the parties slacken:

Canadian parties are intermittent organizations, pumped up in a frenzy of activity when elections are at hand, or nominations or the leadership are at stake, but allowed to go dormant, and sometimes disintegrate, when there is less to be done [4].

These parties are supposed to be responsible for ensuring that Canadians vote. Many Canadians need reminders when elections are near. In addition, Canadians require motivation, political information, and prompt instruction from political parties. It is central for the electorate that political parties engage with the populace as much as possible, during election seasons or not.

Again, considering the encouragement of voter turnout, it is evident that parties are lacking, as they are limited in their engagement with people. Patten writes "while local campaigns and the media could use the parties' websites to stay in touch with the messaging and activities of the national campaign, beyond some simple online surveys, there were limited features aimed at creatively engaging voters" [7]. With widespread technology, there are numerous efficient and effective ways of engaging with people and encouraging them to vote. Instead, with crimes related to new technologies, such as the robo calls the CPC used in 2011, Canadians have experienced creative methods of discouraging voting. Though "it would be wrong to deny that the internet and social media have had a significant impact on the conduct of election campaigns" (Patten), parties could be doing much more in terms of technology and voter turnout [7].

Nevertheless, there have been accounts of parties attempting to genuinely increase voter turnout. In the 2015 Canadian federal election, the LPC outreached to young Canadian voters aged 18-25 [8]. Althia Raj writes "during the 2011 election, Elections Canada estimated, less than 39 per cent of young Canadians cast a ballot. In 2008 , the agency's best guess was that 37 per cent of 18- to 24-year-olds had participated". In 2015, Elections Canada [1] states that the young voter turnout of people aged 18-24 increased to an estimated $57.1 \%$. Though this can still be considered cynically, as if the LPC were simply trying to receive more votes from young people, the $18.1 \%$ increase in young voter turnout is exceptional. Nonetheless, there is probably a degree of overlap with the LPC's specific interest of receiving more votes from people aged 18-24 and their deontological efforts of encouraging people to vote, regardless of which party they vote for. Deontological here meaning moral duty or right action. Evidently, parties are not entirely erroneous concerning voter turnout in Canada.

Next, Elections Canada has itself advertised to Canadians with the purpose of increasing voter turnout. Cameron Anderson and Michael McGregor write about Elections Canada, "during campaign periods, advertisements are run through various media outlets encouraging electors to exercise their democratic right to vote (some ads also provide basic information about when, where and how to vote)" [9]. Elections Canada has advertised during several of the last elections for both the federal and provincial elections. Though Elections Canada aims at advertising to Canadians as a whole, in their advertising they have targeted certain groups of particular concern. These groups include voters under the age of 30, Aboriginal Peoples, ethnic minorities, and people with special needs [9]. The aim of Elections Canada is to encourage more people to vote without being partisan. Anderson and McGregor expect that the exposure to Elections Canada's ads has increased voter turnout, without impacting voters' party preference [9].

It has been established that parties are largely a cause in the voter turnout decline of the 21 st century. Though it is their responsibility to ensure people vote, the main parties have not sufficiently attempted to increase voter turnout. Since it is paramount to Canadian electoral democracy to increase voter turnout, we will treat the issue of political education with relation to increasing voter turnout. Henry Milner writes that "the real threat to democracy ... lies not in the young citizens choosing not to vote, but in their lacking the basic knowledge and skills to make that choice on an informed basis" [10]. He underlines that voter turnout among young Canadians is a crucial factor. He states that even worse is that young voters lack the civic literacy to make informed decisions during elections. Further, Milner believes that innovative educational policies ought to be implemented "from parliament right down to the civics classroom". Cara Bradley argues that information literacy must become a priority for educators in Canada [11]. She argues that the positive social, political, and 
personal results of information literacy will be widespread across Canada, should educators prioritize information literacy.

Furthermore, technology has, and is expected to have, a positive impact on citizens considering voter turnout. The late 20th century to the present is the Information Age. Not only are new and adaptive technologies being invented, but people are becoming more educated with advanced technologies. Optimistically, this is supposed to have a tremendous impact on electoral politics. Patten writes "in terms of electoral politics, political scientists have equated the potential impact of the internet with the rise of television broadcasting in the mid-20th century" [7]. The rise of television broadcasting in the mid-twentieth century was extraordinary. Further, Patten elaborates, stating, "Brad Walchuk, for example, argues that not only will social media allow 'parties to connect to voters and spread their word in entirely new ways,' but it also allows for interactive two-way communications". Innovative educational policies, information literacy, and technological knowledge all coordinate. Educational institutions teach information literacy and technological knowledge; technology, such as the internet, provides information for political literacy. As younger generations' progress and technology develops, a great potential for citizens to acquire political information arises. We predict that the better educated younger generations are, the more voters during elections can be expected.

Next, there is a correlation between voter turnout and education levels among Canadians. Lower education levels mean lower voter turnouts, and higher education levels equates to higher voter turnouts. Steven Tenn states that "an empirical regularity found in numerous studies is that the highly educated are more likely to vote" [12]. To increase education and literacy in Canada, there is one crucial topic of consideration. In Canada, there should be publicly funded postsecondary education. This would mean that tuition, books, and other school related bills would be paid for by the Government of Canada. If students are unable to pay for rent during their study period, then students could apply for housing funds for their time in university. Again, the better education Canadians have, the more likely they are to vote; the more people that have post-secondary education, the more people will vote.

The cost of post-secondary education in Canada for an undergraduate degree averages in over $\$ 50,000.00 \mathrm{CA}$, usually ranging up to $\$ 80,000.00 \mathrm{CA}$ for a four-year undergraduate degree program [13]. This cost only includes food, rent, tuition, books, utilities, and other bills. These statistics were calculated by averaging the general cost of tuition for Canadians per year, including attending summer classes, at $\$ 10,000.00 \mathrm{CA}$ per year, and adding that to $\$ 700.00 \mathrm{CA}$ per month for everything else. The average amount of student loan debt a student incurs by the time of finishing an undergraduate degree is in the "mid- to high- $\$ 20,000.00 \mathrm{CA}$ range. The Canadian Federation of Students pegs it at $\$ 27,000.00 \mathrm{CA}$ " [14]. Evidently, with such high costs of living and university tuition, it is understandable why only " $64.1 \%$ of adults aged 25 to 64 had post-secondary qualifications in 2011", Statistics Canada [15].

Clearly, there would be more adults pursuing post-secondary education if it was publicly funded. The central reason why people do not receive higher education is because of its costs. If there were more adults with, at least, undergraduate degrees, then the voter turnout would be higher in Canada; for, the better educated the citizens; the more likely they are to vote. Instituting this public good is also an opportunity for Canadian political parties to mobilize support among Canadians. There is a significant amount of young people that could vote for a party that was willing to institute publicly funded postsecondary education. The prospect should not be overlooked.

To evidence the likelihood of publicly funded post-secondary education increasing voter turnout, now we will conduct a brief comparative politics analysis. We will use Milner's empirical data from his chapter, "The Problem of Political Drop-outs: Canada in Comparative Perspective," in Canadian Parties in Transition. In this chapter he (2007) provides a table, demonstrating the voter turnout for selected democracies. Countries with a high voter turnout, such as Sweden and Norway, have publicly funded post-secondary education [16]. This public good exists, in some European countries, for European citizens [17]. According to Milner's table from the first round of the European Social Survey (ESS), in Norway, 83.66\% of its people voted [10]. This table also demonstrates that in Sweden, $86.96 \%$ of its people voted. Due to lack of clarity from the ESS, we presume this table is for national elections in, or nearing, 2002; for, Milner's comparative table is derived from the 2002 first round of the ESS (European Social Survey, n.d., sec. 3). The voter turnout percentages for Norway and Sweden are particularly high. Publicly funded postsecondary education cannot account entirely for these high percentages.

Therefore, to further understand these high voter turnout percentages in countries such as Norway and Sweden, we will now analyze the correlation that exists in selected countries with both PR and publicly funded post-secondary education. The PR electoral system that will probably be used in Canada, if Canada endorses a new electoral system by 2019, is the mixed member proportional (MMP) system [18]. Therefore, to make the correlation between PR and publicly funded post-secondary education clearer, we provide a general definition of PR. In PR systems such as MMP, voters cast a vote directly for a party. The votes for each party can be added up to give a total across the country, or across regions. This determines by simple proportionality how many votes each parliamentary party has in the parliament. For the prospective voter, every vote counts (Direct Party and Representative Voting (DPR), n.d.).

In the 21st century, countries in Europe that have PR as an electoral system, tend to have publicly funded post-secondary education. Again, Norway, Finland, and Sweden all have PR (PR Library), and publicly funded post-secondary education. Evidently, PR and publicly funded post-secondary education coordinate when considering voter turnout, since both Norway and Sweden have high voter turnouts [19]. It is paramount to Canada's electoral democracy to consider this data. If Canada's electoral democracy is to survive, then Canadian political parties must adopt similar policies of countries that have a consistently high voter turnout.

Clearly, there exists a correlation between PR, publicly funded postsecondary education, and high voter turnouts. It can be inferred from the evidence provided thus far, that voter turnout is higher in countries such as Norway, Sweden, and Finland, because they have publicly funded post-secondary education and PR. This common good and PR are forms of equality, and "according to the 'law of dispersion', the level of inequality in political participation is higher when voter turnout is low" Ohrvall, et al. [20]. Contrarily, we argue, voter turnout is high when the level of equality is high. The common factor here is equality. Countries that have both PR and publicly funded post-secondary education have a higher level of equality than countries without them. Clearly, considering the electoral crisis in Canadian democracy, levels of equality cannot be overlooked. 
Therefore, to increase voter turnout in Canada, we prescribe that parties and the Canadian government should institute publicly funded post-secondary education and PR as its electoral system. Canada has a publicly funded healthcare system, which is fundamental to Canadians' values. Both publicly funded healthcare and publicly funded postsecondary education are public goods. The majority of Canadians believe in fairness and equity with essential Canadian services. Likewise, publicly funded post-secondary and PR corresponds to the Canadian values of equity and fairness. Publicly funded postsecondary education, publicly funded healthcare, PR, and increasing voter turnout all coincide and coordinate. Parties must take the recent electoral results seriously, that is the results from 2008 and 2011; and, to increase voter turnout, this may mean serious change. Improving the Canadian government's infrastructure, by adapting and creating more public goods, is fundamental to a healthy Canadian electoral democracy.

Further, considering publicly funded post-secondary education, in November 2016, Canadian students across the country protested that education should be a right Yarr [21]. In the Canadian Charter of Rights and Freedoms, part one section seven, it grants the right to life Canadian Charter of Rights and Freedoms [22]. However, the only seeming way of having a good life in Canada, is to have a high education. Kate Dubinski states that "the forum poll ... found that three-quarters of Canadian adults agree a post-secondary education leads to a higher quality of life" [23]. Rights and freedoms in Canada cannot merely be recognized or bestowed upon Canadian citizens. Rather, there must be a substantive degree of economic support and relative common goods to complement political rights. Publicly funding post-secondary education provides this substantial economic support, as Canadians would be able to earn degrees and qualify for better and innovative employment. Though improving infrastructure may seem like a long-term goal, the power and potential of parties should not be underestimated. Again, the electoral crisis cannot be overlooked, and parties have the potential to make the appropriate changes to reverse low voter turnouts.

Nevertheless, publicly funding post-secondary education faces challenges. According to Dubinski's Forum Research poll, of the Canadians asked if they support publicly funded post-secondary, only approximately half supported it [23]. Most of these people were leftleaning in ideology or the less wealthy among Canadians [23]. The poll suggests that people, who are centrist, right-leaning in ideology, and wealthier among Canadians, tend not to believe that Canada should have a publicly funded post-secondary education system. The problem with these people's perceptions is that they are short-sighted and closed-minded. By short-sighted, we mean that they only understand a degree of what they are being asked in this poll, not knowing the ramifications of having this common good. Also, their perception is individually interest-based, as opposed to being collectively interestbased. With a collective vision, publicly funded post-secondary education would not be, necessarily, negative for the Canadian economy. Rather, it would foster the work force. It would provide opportunities for people, regardless of their socio-economic background. This means that there would be more workers for special jobs. It would increase the skill levels among Canadians. Above all, parties could utilize publicly funded post-secondary education to mobilize Canadians into being effective participants in Canada's electoral democracy.

Next, the voting age should be lowered to increase the number of voters among Canadians. Considering only the added quantity of voters from the new range of legally eligible voters, there would, probably, be a greater number of Canadians voting. To understand this, add the number of voters who voted in Canada in the 2015 federal election, plus the new range of voters eligible to vote, which is citizens in Canada aged 16-17. The only way for there to be a decrease in numbers of voters from the 2015 federal election, would be if a percentage of the existing voters, greater than the percentage of new voters, ceased to vote. Overall, there is a greater probability that Canada would have a higher voter turnout with a lower voting age. Again, the governmental mechanic of lowering the voting age is another potentiality for parties to recruit younger citizens that want to be politically active.

Probably, the best age to lower the voting age to is sixteen. This is because sixteen is the average legal age when people may receive their learner's license to drive in Canada Canada's Legal Driving Ages: Province-by-Province [24]. Also, sixteen is the age that people are eligible to work in the Canadian Armed Forces Government of Canada [25]. Lowering the voting age to sixteen to coordinate with these two other ages of eligibility is sensible. Clearly, the institutions that set these ages of eligibility to vote in elections, to work in the Armed Forces, or to receive a learner's license to drive in Canada, are not the same. So, it is understandable that they all do not have the same age limitation.

Lastly, the potential of parties to mobilize Canadians into voting cannot be understated. In the last federal election, the LPC realized this potentiality as they organized and united a significant amount of Canadians. Their new platform promised electoral reform for 2019 Electoral Reform [26], stating that they would update the out-dated single-member plurality electoral system. This rallied a vast proportion of Canadians. The LPC positioned themselves as a party of significant change and reform; and, consequently, recruited younger voters into voting and supporting their party. It should be interesting to discover if the LPC decides to further realize the potentiality of maintaining their promise of electoral reform and fulfilling ambitious infrastructural plans, like creating more public goods. By doing this, they could even secure themselves a second consecutive term in power in 2019. Much of Canadian support, especially those LPC voters that lean to the left in ideology and are younger in age, relies on the LPC fulfilling the crucial promise on electoral reform, as well as completing futuristic infrastructural goals.

The GPC should not be discounted in terms of parties' responsibility to increase voter turnout. Even as a small party, they still have managed to support the increase in voter turnout. The GPC has made the proposition that the Canadian government should reform the electoral system into a PR system Democratic Renewal and Proportional Representation [27]. They have focused their powers and attention on ensuring that the LPC fulfils their promise on electoral reform. The GPC has proposed that a form of PR, like a mixed PR, would be the best electoral system to adopt. Clearly, then, we cannot state that all major parties have contributed to the general decline in voter turnout, as the GPC is working to ensure that the LPC reforms the electoral system. Nevertheless, being a small party, the GPC is limited in its ability to pursue many policies.

In sum, it has been signified that Canada, in the 21st century, is undergoing an electoral crisis. In the 2008 federal election, Canadian voter turnout was a mere $58.8 \%$ (Elections Canada [2]. It is the responsibility of parties to encourage more people to vote. Instead, though some parties like the LPC have contributed to an increase in the voter turnout in Canada, Canadian political parties, especially the $\mathrm{CPC}$, is a cause of the decline in voter turnout. Technology is a 
Page 5 of 5

potential prospect for electoral politics, and it has been underlined that parties have insufficiently utilized and improvised new technologies for electoral purposes. Further, we have demonstrated that the degree of political literacy is a relevant factor in voter turnouts in Canada, arguing that to increase voter turnout the Canadian government and parties should increase political and information literacy among Canadians. In addition, Canada's regime is compatible with publicly funded post-secondary education and PR. With such systems as Canada's publicly funded healthcare, Canadians hold the values of fairness and equity. The common value in publicly funded postsecondary education and PR is equality $[28,29]$. Arguably, the higher the levels of equality, the higher voter turnout will be. Publicly funded post-secondary education, $\mathrm{PR}$, and high voter turnouts all coordinate. This has been established, empirically, from the case study of Norway and Sweden. A defense for publicly funded post-secondary education has also been provided; we claim that it would have positive effects on the Canadian economy. Further, we have recommended that the age to vote should be lowered to sixteen. PR, publicly funded post-secondary education, and lowering the voting age to sixteen would all increase voter turnout, in order to solve the electoral crisis. Finally, there is a great potential that the LPC will win the 2019 federal election if they can maintain the support of the electorate by fulfilling their electoral reform promise $[30,31]$. It has been highlighted that the success the LPC has had by uniting voters on the center and left in ideology, as well as recruiting younger people into voting, should not be understated. It has also been noted that the GPC has made the proposition that Canada should have PR. It should be interesting to see what steps parties will take in the upcoming years to increase voter turnout; for, there is a great prospect in electoral reform and the instituting of public goods for parties.

\section{Discussion}

Voting is the most effective part of civil and cultural society. Now a days socialistic countries are not supporting socialistic methods in society due to this risk is generated in entire society and it leads to unstoppable crisis in elections. Voters in the community are participating anti-social elements in electoral constitutions due to the force of politicians, Corruption also, socialistic people would not enhance this in society, it should be aware to all people then it will be like a good social movement. If society is good then Country will be good. Socialistic behaviour in electoral techniques will avoid crisis in all systems in Human races.

\section{References}

1. Voter Turnout by Age Group (2016) Chart illustration Voter Turnout by Age Group 2011 and 2015 General Elections, Elections Canada.

2. Voter Turnout at Federal Elections and Referendums (2015) Elections Canada.

3. LaRochelle-Cote S, Uppal S (2012) Factors Associated with Voting. Perspectives on Labour and Income 24: 4-15.

4. Wolinetz S (2007) Cycles and Brokerage: Canadian Parties as Mobilizers of Interest. In: Gagnon A, Tanguay A (eds.) Canadian Parties in Transition (3rdedn), Orchard Park NY; Peterborough ON; Plymouth UK; Sydney NSW: Broadview Press, pp: 179-196.

5. Keys Facts and Timeline of Events Surrounding the Robocalls Scandal (2014) The Canadian Press.
6. LaMontagne B, Scruggs L, Stockemer D (2011) Bribes and Ballots: The Impact of Corruption on Voter Turnout in Democracies. International Political Science Review 34: 74-90.

7. Patten S (2013) Assessing the Potential of New Social Media. Canadian Parliamentary Review 36: 21-26.

8. Raj A (2016) Liberals Won Majority Thanks to Young Voters Poll Suggests. The Huffington Post.

9. Anderson C, McGregor M (2014) The Effects of Elections Canada's Campaign Period Advertising. Canadian Journal of Political Science 47: 813-826.

10. Milner H (2007) [Table illustration Voter Turnout in Selected Democracies 2007] The Problem of Political Drop-outs: Canada in Comparative Perspective. In: Gagnon A, Tanguay A (eds.) Canadian Parties in Transition (3rdedn) Orchard Park NY; Peterborough ON; Plymouth UK; Sydney NSW: Broadview Press, pp: 437-465.

11. Bradley C (2013) Information Literacy Policy Development in Canada: Is It Time?. Partnership: the Canadian Journal of Library and Information Practice and Research 8: 1-28.

12. Tenn S (2007) The Effect of Education on Voter Turnout. Political Analysis 15: 446-464.

13. Collier S (2015) How Much Does It Cost to Study in Canada?

14. Sagan A (2014) Average Student Debt Difficult to Pay Off Delays. Life Milestones Canadian Broadcasting Corporation.

15. Statistics Canada (2016) Education in Canada: Attainment Field of Study and Location of Study.

16. Välimaa J (2015) Why Finland and Norway Still Shun University Tuition Fees - Even for International Students. The Conversation.

17. Your Europe (2016) EuropeEU.

18. Day W (2016) Proportional representation: What would it look like? Inroads 38: 62-66.

19. PR Library (2006) Proportional Representation Voting Systems.

20. Öhrvall R, Persson M, Solevid M (2013) Voter Turnout and Political Equality: Testing the 'Law of Dispersion' in a Swedish Natural Experiment Politics 33: 172-184.

21. Yarr K (2016) 'Education for All Should Be Our Right': PEI Protest Demands Free Post-Secondary Education. Canadian Broadcasting Incorporation.

22. Canadian Charter of Rights and Freedoms (2016) Constitution Act 1982.

23. Dubinski K (2015) Majority of Canadians say students shouldn't have to pay to go to college and university new poll suggests. The London Free Press.

24. Canada's Legal Driving Ages: Province-by-Province (2013) Value Car and Truck Rental.

25. Government of Canada (2016) Frequently Asked Questions. National Defense and the Canadian Armed Forces.

26. Electoral Reform (2018) Liberal Party of Canada

27. Democratic Renewal and Proportional Representation (2016) Green Party of Canada.

28. Direct Party and Representative Voting (DPR) (nd) Voting Systems Compared with Special Reference to STV.

29. Forty-Second General Election 2015: Voting Results (2016) Elections Canada.

30. European Social Survey (nd) Based on Data from the First Round of the European Social Survey.

31. Summary Investigation Report on Robocalls (2014) Commissioner of Canada Elections. 